\title{
Trace Element Content and Antioxidant Capacity of Gluten-Free Snacks Produced for Coeliac Disease Patients
}

\author{
Görkem Yalçın
}

\begin{abstract}
Trace element levels and antioxidant capacities of different gluten-free snacks were investigated in this study. Samples were digested by using microwave system. $\mathrm{Na}, \mathrm{Mg}, \mathrm{K}, \mathrm{Ca}, \mathrm{Fe}, \mathrm{Zn}, \mathrm{Cu}$ and $\mathrm{Mn}$ levels were determined by inductively coupled plasma mass spectrometry. Cupric reducing antioxidant capacity and 2,2-diphenyl-1-picrylhydrazyl radical scavenging capacity methods were used to evaluate antioxidant capacity. $\mathrm{Na}, \mathrm{Mg}, \mathrm{K}$,
\end{abstract}

$\mathrm{Ca}, \mathrm{Fe}, \mathrm{Zn}, \mathrm{Cu}$ and $\mathrm{Mn}$ levels were found in the range of 43.77

- $4905 \mathrm{mg} / \mathrm{kg}, 47.15$ - $751 \mathrm{mg} / \mathrm{kg}, 44.84$ - $2156 \mathrm{mg} / \mathrm{kg}, 95.29$

- $1616 \mathrm{mg} / \mathrm{kg}, 69.70$ - $144 \mathrm{mg} / \mathrm{kg}, 5.92$ - $41.28 \mathrm{mg} / \mathrm{kg}, 3.57$ -

$13.25 \mathrm{mg} / \mathrm{kg}$ and $5.20-12.06 \mathrm{mg} / \mathrm{kg}$, respectively. The highest antioxidant capacity value was obtained from orange bar in both antioxidant capacity assays.

Keywords: Coeliac disease, Snack, Trace element, Antioxidant
Görkem Yalçın

Department of Analytical Chemistry, Faculty of Pharmacy, Ege University, 35100, Bornova, Izmir, Turkey

Corresponding Author:

Görkem Yalçın

e-mail:gorkemy1@gmail.com,gorkem.yalcin@ege.edu.tr

Submitted / Gönderilme: 14.02 .2017

Revised / Düzeltme: 07.04.2017

\section{INTRODUCTION}

Coeliac disease is a chronic autoimmune disorder that occurs in response to gluten in the small intestine of sensitive individuals. It leads to malabsorption, diarrhoea, weight loss, fatigue and anaemia (1). Epidemiological studies have shown that the prevalence of this disease is approximately $1 \%$ of the population throughout the world (2). Tatar et al. (3) reported the prevalence of coeliac disease in the Turkish population was $1.3 \%$. Coeliac disease is a life-long disease and the only effective cure is a gluten-free diet $(4,5)$.

Since trace elements play important roles in human biological processes, they are essential micro nutrients in the human daily diet (6). However, previous studies have indicated that glutenfree diet may lead to malnutrition of trace elements (7). In addition, strict adherence to a gluten-free diet may also induce inadequate intake of the essential nutrients such as vitamins and dietary fibres in coeliac disease patients due to the poor nutritional components of packaged gluten-free products $(7,8)$. Therefore, it is necessary to examine the nutritional quality of gluten-free products in order to prevent nutritional deficiencies of individuals suffering from coeliac disease.

Many analytical techniques have been developed in order to determine trace element contents of food samples such as flame atomic absorption spectrometry, electrothermal atomic absorption spectrometry, inductively coupled plasma optical 
emission spectrometry and inductively coupled plasma mass spectrometry (ICP-MS) $(9,10)$. In particular, the ICP-MS has been widely used due to its distinct advantages, including sensitivity, selectivity and simultaneous multi-element analysis capability $(11,12)$.

Gluten-free diet has an important effect on daily life of coeliac disease patients. They have to exclude foods including gluten. This situation leads them to consume more packaged special products. Because of all these reasons mentioned above, the aim of this study was to investigate trace element levels by ICP-MS and antioxidant properties snacks produced for coeliac disease patients.

\section{MATERIAL AND METHODS}

\section{Samples}

6 different widely consumed snack samples of different brands were purchased in 2016 from local supermarkets in Izmir city (Turkey). Samples were classified and coded as cookie with orange (A), cookie with olive and thyme (B), cookie with cacao (C), orange bar (D), strawberry bar (E) and chocolate bar $(\mathrm{F})$.

\section{Trace element analysis}

$\mathrm{Na}, \mathrm{Mg}, \mathrm{K}, \mathrm{Ca}, \mathrm{Fe}, \mathrm{Zn}, \mathrm{Cu}$ and $\mathrm{Mn}$ levels of samples were analysed by Perkin Elmer Nexion 300D ICP-MS (Norwalk, CT, USA). After all samples were ground in a porcelain mortar, $0.5 \mathrm{~g}$ of each sample was weighed directly into digestion vessel. $5 \mathrm{~mL}$ of $\mathrm{HNO}_{3}(69 \%)$ (Merck, Darmstadt, Germany) and $2 \mathrm{~mL}$ of $\mathrm{H}_{2} \mathrm{O}_{2}$ (30\%) (Sigma-Aldrich, Saint Louis, MO, USA) were added to each vessel and digested using Berghof speedwave two microwave system (Eningen, Germany). The operating procedure was as follows: $5 \mathrm{~min}$ at $145^{\circ} \mathrm{C}, 15 \mathrm{~min}$ at $190^{\circ} \mathrm{C}$ and $15 \mathrm{~min}$ at $75^{\circ} \mathrm{C}$. Blank was prepared in the same way. Before ICP-MS detection, digested samples were diluted to final volume of $50 \mathrm{~mL}$ with ultrapure water. The operating conditions of the instrument were set as: RF power $1100 \mathrm{~W}$, argon gas flow rate $18.00 \mathrm{~L} / \mathrm{min}$, auxiliary gas flow rate $1.20 \mathrm{~L} / \mathrm{min}$ and nebulizer gas flow rate $0.98 \mathrm{~L} / \mathrm{min}$. Single element standard solutions (Perkin Elmer, Norwalk, CT, USA) were used to prepare the calibration standards in the concentration range 1-1000 $\mu \mathrm{g} / \mathrm{L}$. All experiments were performed in triplicate.

\section{Antioxidant capacity analysis}

$2 \mathrm{~g}$ of ground snack samples were extracted with $10 \mathrm{~mL}$ of methanol in ultrasonic bath for $30 \mathrm{~min}$. After the filtrates were collected, residues were reextracted under the same condition. The two filtrates were mixed and used for the evaluation of antioxidant capacity by cupric reducing antioxidant capacity (CUPRAC) and 2,2-diphenyl-1picrylhydrazyl radical scavenging capacity (DPPH) assays.

The DPPH values were estimated using the method described by Brand-Williams et al. (13). Briefly, $2.5 \mathrm{~mL}$ of $0.1 \mathrm{mM}$ DPPH radical solution and $0.25 \mathrm{~mL}$ of sample were mixed and allowing the mixture to react for $30 \mathrm{~min}$ at room temperature in the dark. The absorbance was measured at $517 \mathrm{~nm}$ using Thermo Evolution Array UV-visible spectrophotometer (Waltham, MA, USA). Trolox (0.02-0.50 mM) was used as a reference standard. Results were expressed as $\mu \mathrm{mol} / \mathrm{g}$ Trolox equivalent (TE).

The CUPRAC assay was carried out according to Apak et al. (14). An aliquot $(0.1 \mathrm{~mL})$ of sample was mixed with $0.5 \mathrm{~mL}$ copper (II) chloride (10 mM), $0.5 \mathrm{~mL}$ neocuproine $(7.5 \mathrm{mM})$, $0.5 \mathrm{~mL}$ ammonium acetate buffer $(1 \mathrm{M}, \mathrm{pH}=7.0)$ and $0.5 \mathrm{~mL}$ water. The absorbance of the mixture was measured at 450 $\mathrm{nm}$ after 30 min using Thermo Evolution Array UV-visible spectrophotometer (Waltham, MA, USA). Trolox (0.02$0.50 \mathrm{mM}$ ) was used as a reference standard. Results were expressed as $\mu \mathrm{mol} / \mathrm{g}$ TE.

\section{RESULTS AND DISCUSSION}

\section{Trace element analysis}

The results of the concentration values of $\mathrm{Na}, \mathrm{Mg}, \mathrm{K}, \mathrm{Ca}, \mathrm{Fe}$, $\mathrm{Zn}, \mathrm{Cu}$ and $\mathrm{Mn}$ in the gluten-free snack samples are shown in Table 1.

The Na content of samples ranged from 43.77-4905 mg/kg. The highest level was detected in sample B. According to Commission of the European Communities, high Na content and low Na content are defined as $>5000 \mathrm{mg} / \mathrm{kg}$ and $<1200$ $\mathrm{mg} / \mathrm{kg}$, respectively (15). Therefore, results indicate that none of the samples contain high levels of $\mathrm{Na}$ concentrations. On the other hand, K levels of samples ranged from 44.84 to $2156 \mathrm{mg} / \mathrm{kg}$. Missbach et al. (15) investigated the $\mathrm{Na}$ and $\mathrm{K}$ levels of gluten-free products and their results ranged from 162.0 to $4179.1 \mathrm{mg} / \mathrm{kg}$ and 799.7 to $4769.2 \mathrm{mg} / \mathrm{kg}$ for cookie and cakes, respectively.

As seen in Table 1. Ca and Mg contents of samples ranged from $95.29-1616 \mathrm{mg} / \mathrm{kg}$ and $47.15-751 \mathrm{mg} / \mathrm{kg}$, respectively. The maximum $\mathrm{Ca}$ and $\mathrm{Mg}$ levels were found in the samples $\mathrm{B}$ and $\mathrm{D}$, respectively. Coeliac disease patients that carry out gluten-free diet could be negatively affected due to the lack of minerals such as $\mathrm{Ca}$ and $\mathrm{Mg}$ in gluten free products (8). 
Table 1. Trace element levels of gluten free snacks.

\begin{tabular}{c|cccccc}
\hline \multirow{2}{*}{$\begin{array}{c}\text { Trace elements } \\
(\mathbf{m g} / \mathbf{k g})\end{array}$} & \multicolumn{7}{|c}{ SAMPLES } \\
\cline { 2 - 7 } & $\mathbf{A}$ & $\mathbf{B}$ & $\mathbf{C}$ & $\mathbf{D}$ & $\mathrm{E}$ & $\mathbf{F}$ \\
\hline $\mathbf{N a}$ & $867.03 \pm 1.40$ & $4905.00 \pm 42.29$ & $1262.18 \pm 1.84$ & $43.77 \pm 1.75$ & $156.93 \pm 0.96$ & $153.59 \pm 1.18$ \\
$\mathbf{M g}$ & $47.15 \pm 1.57$ & $122.60 \pm 2.42$ & $379.10 \pm 1.20$ & $751.18 \pm 6.48$ & $642.82 \pm 3.71$ & $622.12 \pm 5.24$ \\
$\mathbf{K}$ & $44.84 \pm 5.37$ & $1337.70 \pm 9.63$ & $2025.62 \pm 8.67$ & $2156.09 \pm 17.32$ & $2070.78 \pm 5.31$ & $2073.75 \pm 13.53$ \\
$\mathbf{C a}$ & $95.29 \pm 9.11$ & $1616.19 \pm 52.64$ & $370.98 \pm 4.55$ & $324.42 \pm 13.95$ & $736.73 \pm 3.28$ & $747.83 \pm 37.69$ \\
Fe & $69.70 \pm 3.71$ & $84.90 \pm 1.71$ & $92.53 \pm 1.62$ & $144.82 \pm 6.16$ & $113.65 \pm 1.23$ & $120.36 \pm 5.21$ \\
Zn & $5.92 \pm 0.16$ & $9.20 \pm 0.17$ & $11.39 \pm 0.15$ & $13.62 \pm 0.55$ & $13.11 \pm 0.17$ & $41.28 \pm 2.58$ \\
Cu & $3.57 \pm 0.57$ & $5.56 \pm 0.15$ & $6.74 \pm 0.10$ & $9.69 \pm 0.37$ & $7.97 \pm 0.06$ & $13.25 \pm 0.92$ \\
Mn & $5.20 \pm 0.01$ & $5.42 \pm 0.01$ & $7.37 \pm 0.04$ & $12.06 \pm 0.33$ & $11.61 \pm 0.04$ & $11.24 \pm 0.36$ \\
\hline
\end{tabular}

Results are expressed as means \pm SD. Cookie with orange (A), cookie with olive and thyme (B), cookie with cacao (C), orange bar (D), strawberry bar (E), chocolate bar (F).

Therefore, consumption of samples B and D may contribute to sufficient intake of these minerals in coeliac individuals. Filipcev et al. (16) determined mineral content of gluten-free cookies enriched with molasses. They reported 1302.9 and $876.1 \mathrm{mg} / \mathrm{kg} \mathrm{Ca}$ and $\mathrm{Mg}$ levels, respectively for cookies in control group.

Fe and $\mathrm{Zn}$ play important roles in regulation of biological functions. Their deficiencies cause serious disorders in human body (17). As shown in Table 1. Fe and $\mathrm{Zn}$ concentrations of samples varied from 69.70 to $144 \mathrm{mg} / \mathrm{kg}$ and from 5.92 to $41.28 \mathrm{mg} / \mathrm{kg}$, respectively. The highest Fe and $\mathrm{Zn}$ concentrations were measured in samples $\mathrm{D}$ and $\mathrm{F}$, respectively. The data reported in the literature (18) ranged between 1.1-99.0 $\mathrm{mg} / \mathrm{kg}$ and 1.1-137.0 $\mathrm{mg} / \mathrm{kg}$ for $\mathrm{Fe}$ and $\mathrm{Zn}$ levels in gluten-free food samples, respectively.

In human, $\mathrm{Cu}$ and $\mathrm{Mn}$ participate in vital metabolism functions. They play important roles in different enzyme systems (19). In the present study, the highest $\mathrm{Cu}$ and Mn concentrations were determined in samples $F$ and $D$, respectively. The $\mathrm{Cu}$ and $\mathrm{Mn}$ levels found for analysed samples are comparable with those reported by Hidalgo et al. (20). Their results obtained for gluten-free amaranth bar samples ranged from 1.80 to $6.12 \mathrm{mg} / \mathrm{kg}$ and from 6.50 to $10.60 \mathrm{mg} / \mathrm{kg}$ for $\mathrm{Cu}$ and $\mathrm{Mn}$, respectively.

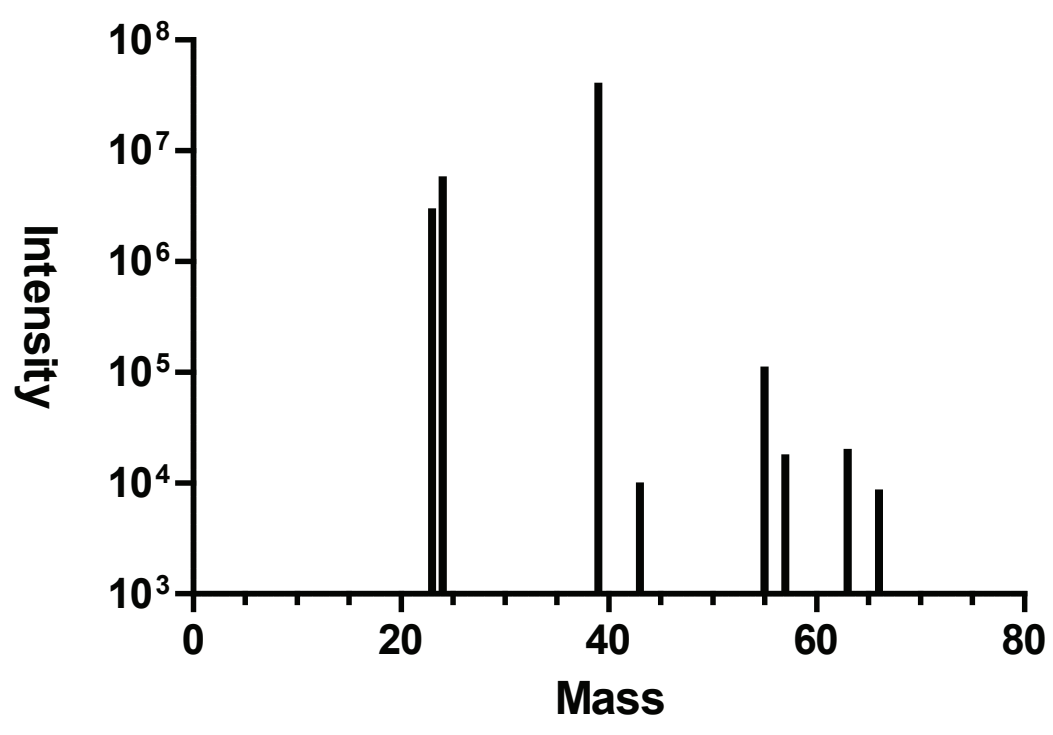

Figure 1. Representative ICP-MS spectrum obtained from sample E. The measured element lines; Na: $23 \mathrm{amu}, \mathrm{Mg}: 24 \mathrm{amu}$, K: 39 amu, Ca: 43 amu, Mn: $55 \mathrm{amu}$, Fe: $57 \mathrm{amu}, \mathrm{Cu}: 63 \mathrm{amu}$ and Zn: $66 \mathrm{amu}$. 
Table 2. Antioxidant capacity values ( $\mu \mathrm{mol} / \mathrm{g}$ TE) of gluten free snacks examined by two different methods.

\begin{tabular}{c|cccccc}
\hline \multirow{2}{*}{$\begin{array}{c}\text { Antioxidant } \\
\text { Capacity }\end{array}$} & A & B & C & D & E & F \\
\cline { 2 - 7 } & $10.66 \pm 0.87$ & $6.86 \pm 0.69$ & $13.44 \pm 0.25$ & $17.19 \pm 1.52$ & $5.01 \pm 0.17$ & $4.66 \pm 0.40$ \\
CUPRAC & $1.18 \pm 0.08$ & $1.50 \pm 0.10$ & $3.55 \pm 0.23$ & $5.49 \pm 0.25$ & $1.90 \pm 0.12$ & $1.71 \pm 0.14$ \\
DPPH & & &
\end{tabular}

Results are expressed as means \pm SD. Cookie with orange (A), cookie with olive and thyme (B), cookie with cacao (C), orange bar (D), strawberry bar (E), chocolate bar (F).

\section{Antioxidant capacity analysis}

Due to the limitations of antioxidant capacity assays, it is recommended that antioxidant capacity evaluation of samples should be made with at least two different assays in order to obtain accurate results (21). Therefore, DPPH and CUPRAC assays were conducted to investigate the antioxidant capacity of samples. The findings of this study (Table 2) showed that all samples had antioxidant activities. The highest values were obtained from sample $\mathrm{D}$, followed by $\mathrm{C}$ in both DPPH and CUPRAC assays. Results obtained by using DPPH method varied between 1.18-5.49 $\mu \mathrm{mol} / \mathrm{g}$ TE, while values ranged from 4.66 to $17.19 \mu \mathrm{mol} / \mathrm{g}$ TE in CUPRAC assays. Wronkowska et al. (22) reported that the highest DPPH value of buckwheat enhanced gluten-free bread was $2.56 \mu \mathrm{mol} / \mathrm{g}$ TE. Apart from this, Sakac et al. (23) demonstrated that glutenfree rice and buckwheat cookies analysed in their study exhibited antioxidant activity against DPPH radicals. On the other hand, there is no literature about the CUPRAC values of gluten-free products.

\section{Çölyak Hastaları İçin Üretilen Glutensiz Atıştırmalıkların Eser Element İçeriği ve Antioksidan Kapasitesi}

\section{ÖZ}

Bu çalışmada farklı glütensiz atıştırmalıkların eser element seviyeleri ve antioksidan kapasiteleri araştırıldı. Örnekler mikrodalga sistem kullanılarak çözünürleştirildi. Na, $\mathrm{Mg}, \mathrm{K}, \mathrm{Ca}, \mathrm{Fe}, \mathrm{Zn}, \mathrm{Cu}$ ve $\mathrm{Mn}$ düzeyleri indüktif eşleşmiş plazma kütle spektrometresi ile saptandı. Antioksidan kapasiteyi belirlemek için bakır indirgeme antioksidan

\section{CONCLUSIONS}

Gluten-free foods are special products produced for individuals with coeliac disease. Nutritional quality of gluten-free products may be lower. Hence, the present study pointed out the essential element levels and antioxidant properties to reveal the nutritional quality of these products. The findings indicated that snack products analysed in this study have antioxidant properties. Trace element levels of samples showed variations. Considering the recommended daily intake of essential elements, all the samples provide contribution to daily diet of subjects with coeliac disease. Therefore, it is concluded that consumption of gluten-free snacks may reduce the risk of free radicals induced diseases and provide improvement of intake of essential micro nutrients.

\section{ACKNOWLEDGEMENTS}

The author wish to thank Ege University Faculty of Pharmacy Pharmaceutical Sciences Research Centre (FABAL).

kapasite ve 2,2-difenil-1-pikrilhidrazil radikali süpürme kapasitesi yöntemleri kullanıldı. $\mathrm{Na}, \mathrm{Mg}, \mathrm{K}, \mathrm{Ca}, \mathrm{Fe}, \mathrm{Zn}$, $\mathrm{Cu}$ ve $\mathrm{Mn}$ düzeyleri sirasiyla 43.77 - $4905 \mathrm{mg} / \mathrm{kg}, 47.15$ - $751 \mathrm{mg} / \mathrm{kg}, 44.84-2156 \mathrm{mg} / \mathrm{kg}, 95.29-1616 \mathrm{mg} / \mathrm{kg}$, $69.70-144 \mathrm{mg} / \mathrm{kg}, 5.92-41.28 \mathrm{mg} / \mathrm{kg}, 3.57-13.25 \mathrm{mg} /$ $\mathrm{kg}$ ve $5.20-12.06 \mathrm{mg} / \mathrm{kg}$ aralığında bulundu. En yüksek antioksidan kapasite değeri her iki antioksidan kapasite analizinde de portakallı bardan elde edildi.

Anahtar kelimeler: Çölyak hastalığı, Atıştırmalık, Eser element, Antioksidan 


\section{REFERENCES}

1. Rashtak S, Murray JA. Review article: coeliac disease, new approaches to therapy. Aliment Pharm Therap 2012; 35: 76881.

2. Nylund L, Kaukinen K, Lindfors K. The microbiota as a component of the celiac disease and non-celiac gluten sensitivity. Clin Nutr 2016; 6: 17-24.

3. Tatar G, Elsurer R, Simsek H, Balaban YH, Hascelik G, Ozcebe OI, Buyukasik Y, Sokmensuer C. Screening of tissue transglutaminase antibody in healthy blood donors for celiac disease screening in the Turkish population. Digest Dis Sci 2004; 49: 1479-84.

4. Rosell CM, Barro F, Sousa C, Mena MC. Cereals for developing gluten-free products and analytical tools for gluten detection. J Cereal Sci 2014; 59: 354-64.

5. Wagner G, Zeiler M, Grylli V, Berger G, Huber WD, Woeber C, Rhind C, Karwautz A. Coeliac disease in adolescence: Coping strategies and personality factors affecting compliance with gluten-free diet. Appetite 2016; 101: 55-61.

6. Hua Z, Yu WZ, Xin Y, Tian ZH, Chun ZY, Jun DA, Jing JJW. Determination of free amino acids and 18 elements in freezedried strawberry and blueberry fruit using an Amino Acid Analyzer and ICP-MS with micro-wave digestion. Food Chem 2014; 147: 189-94.

7. Saturni L, Ferretti G, Bacchetti T. The gluten-free diet: Safety and nutritional quality. Nutrients 2010; 2: 16-34.

8. Jubete LA, Arendt EK, Gallagher E. Nutritive value of pseudocereals and their increasing use as functional glutenfree ingredients. Trends Food Sci Tech 2010; 21: 106-13.

9. Bressy FC, Brito GB, Barbosa IS, Teixeira LSG, Korn MGA. Determination of trace element concentrations in tomato samples at different stages of maturation by ICP OES and ICP-MS following microwave-assisted digestion. Microchem J 2013; 109: 145-9.

10. Nardi EP, Evangelista FS, Tormen L, Pierre TDS, Curtius AJ, Souza SSD, Barbosa FJ. The use of inductively coupled plasma mass spectrometry (ICP-MS) for the determination of toxic and essential elements in different types of food samples. Food Chem 2009; 112: 727-32.

11. Khan N, Choi JY, Nho EY, Jamila N, Habte G, Hong JH, Hwang IM, Kim KS. Determination of minor and trace elements in aromatic spices by micro-wave assisted digestion and inductively coupled plasma-mass spectrometry. Food Chem 2014; 158: 200-6.
12. Martinez EJL, Barrales PO, Cordova MLFD, Vidal AD, Medina AR. Investigation by ICP-MS of trace element levels in vegetable edible oils produced in Spain. Food Chem 2011; 127: $1257-62$.

13. Brand-Williams W, Cuvelier ME, Berset C. Use of a free radical method to evaluate antioxidant activity. Lebensm Wiss Technol 1995; 28: 25-30.

14. Apak R, Güçlü K, Özyürek M, Çelik SE. Mechanism of antioxidant capacity assays and the CUPRAC (cupric ion reducing antioxidant capacity) assay. Microchim Acta 2008; 160: 413-9.

15. Missbach B, Schwingshackl L, Billmann A, Mystek A, Hickelsberger M, Bauer G, König J. Gluten- free food database: The nutritional quality and cost of packaged gluten-free foods. PeerJ 2015; 3:e1337

16. Filipcev B, Misan A, Saric B, Simurina O. Sugar beet molasses as an ingredient to enhance the nutritional and functional properties of gluten-free cookies. Int J Food Sci Nutr 2016; 67: 249-56.

17. Singh P, Prasad S, Aalbersberg W. Bioavailability of Fe and $\mathrm{Zn}$ in selected legumes, cereals, meat and milk products consumed in Fiji. Food Chem 2016; 207: 125-31.

18. Orecchio S, Amorello D, Raso M, Barreca S, Lino C, Di Gaudio F. Determination of trace elements in gluten-free food for celiac people by ICP-MS. Microchem J 2014; 116: 163-72.

19. Fraga CG. Relevance, essentiality and toxicity of trace elements in human health. Mol Aspects Med 2005; 26: 235-44.

20. Hidalgo MJ, Sgroppo SC, Camina JM, Marchevsky EJ, Pellerano RG. Trace element concentrations in commercial gluten-free amaranth bars. Food Measure 2015; 9: 426-34.

21. Zegarac JP, Valek L, Martinez S, Belscak A. Fluctuations in the phenolic content and antioxidant capacity of dark fruit juices in refrigerated storage. Food Chem 2009; 113: 394-400.

22. Wronkowska M, Zielinska D, Nowak DS, Troszynska A, Smietana MS. Antioxidative and reducing capacity, macroelements content and sensorial properties of buckwheat-enhanced gluten-free bread. Int J Food Sci Tech 2010; 45: 1993-2000.

23. Sakac M, Pestoric M, Misan A, Nedeljkovic N, Jambrec D, Jovanov P, Banjac V, Torbica A, Hadnadev M, Mandic A. Antioxidant capacity, mineral content and sensory properties of gluten-free rice and buckwheat cookies. Food Technol Biotech 2015; 53: 38-47. 